Journal of Agricultural Sciences
(Tarim Bilimleri Dergisi)

\title{
Role of Controlled Atmosphere, Ultra Low Oxygen or Dynamic Controlled Atmosphere Conditions on Quality Characteristics of 'Scarlet Spur' Apple Fruit
}

\author{
Cemile Ebru ONURSAL ${ }^{\text {a* }}$ (D), Mehmet Ali KOYUNCU ${ }^{b}$ id \\ ${ }^{a}$ Bati Akdeniz Agricultural Research Institute, Antalya, TURKEY

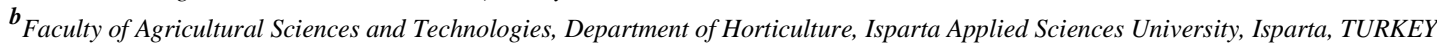 \\ ARTICLE INFO \\ Research Article \\ Corresponding Author: Cemile Ebru ONURSAL, E-mail: ebru.onursal@gmail.com \\ Received: 11 October 2019 / Revised: 07 November 2019 / Accepted: 15 December 2019/ Online: 04 September 2021
}

\section{ABSTRACT}

In this study, the effects of three cold storage technologies, (i) controlled atmosphere-CA $\left(\mathrm{CO}_{2} 4 \%, \mathrm{O}_{2} 3 \%\right)$, (ii) ultra low oxygen-ULO and (iii) dynamic controlled atmosphere-DCA, were investigated on fruit quality of 'Scarlet Spur' apples stored during 10 months plus 7 days of shelf life at $20{ }^{\circ} \mathrm{C}$. After harvest, apples were stored at $0{ }^{\circ} \mathrm{C}$ and $90 \pm 5 \%$ relative humidity during 10 months in CA, $\mathrm{ULO}\left(\mathrm{CO}_{2} 3 \%, \mathrm{O}_{2} 1 \%\right.$, ) and DCA $\left(\mathrm{CO}_{2} 1 \%, \mathrm{O}_{2} \quad 0.5 \%\right)$ conditions. HarvestWatch ${ }^{\mathrm{TM}}$ sensors were used for assessment of lower oxygen limit (LOL) of fruit during DCA storage.
DCA was the best storage condition suppressing ethylene synthesis and respiration rate during storage. The ULO and DCA conditions showed similar results in the maintenance of firmness and TA amount. Weight loss in these conditions was also lower than CA. No significant difference was observed between storage conditions in terms of SSC. DCA technology gave better results in maintaining color of 'Scarlet Spur' than other conditions during cold storage. Result showed that; ULO and DCA conditions were more effective in maintaining quality compared to $\mathrm{CA}$ in terms of all quality parameters.

Keywords: Apple, Controlled atmosphere, Postharvest, Cold storage, Chlorophyll fluorescence

(C) Ankara University, Faculty of Agriculture

\section{Introduction}

Controlled atmosphere (CA) storage is a widely used technology for the storage of apple which is one of the most produced and consumed fruit in the world. Reducing the oxygen $\left(\mathrm{O}_{2}\right)$ concentration in the storage atmosphere and increasing the concentration of carbon dioxide $\left(\mathrm{CO}_{2}\right)$ is the most important factors for prolonging storage period in CA storage technology. Thus fruit quality is kept for longer periods, and postharvest losses during storage are reduced (Both et al. 2014). The possibility to obtain the longest storage period in CA conditions depends on (i) fruit maturity at harvest time, (ii) atmosphere composition during storage and (iii) the cultivar (Thompson 2010).

Storage under proper conditions plays an important role in maintaining product quality especially in climacteric fruit such as apples (Bertone et al. 2012). The main purpose of optimizing the CA storage conditions is to prevent ripening and aging of the fruit by decreasing $\mathrm{O}_{2}$ level and reducing respiration rate and ethylene production (Veltman et al. 2003). Suppressing respiration rate and ethylene synthesis of fruit are the key postharvest processes throughout cold storage (Wright et al. 2015). $\mathrm{O}_{2}$ is the most important factor to decrease metabolic activity and reduce biochemical changes after harvest. Therefore, the use of low $\mathrm{O}_{2}$ levels in storage is an important potential (Tuna Gunes \& Horzum 2017).

The equipment developed in CA storage technology has allowed to work at low $\mathrm{O}_{2}$ or ultra low oxygen (ULO) conditions (Batu \& Sen 2014). Standard CA storage involves keeping the oxygen content at 2-3\% while the $\mathrm{O}_{2}$ level in the ULO conditions can be reduced to $1 \%$. ULO storage is more successful than standard CA technology in terms of preventing disease and physiological disorders (Balla \& Holb 2007; Mattè et al. 2005). Additionally, it can protect some quality characteristics such as fruit flesh firmness and ground color better than standard CA storage procedure (Thewes et al. 2015). In developed countries, ULO storage has been extensively used in fruit industry in order to maintain fruit quality for a longer period (Watkins 2008).

Dynamic controlled atmosphere (DCA) is the new and popular technology in apple industry (Mditshwa et al. 2018). During DCA storage, $\mathrm{O}_{2}$ level is reduced to the lowest level that the fruit can tolerate which is just above the so-called critical $\mathrm{O}_{2}$ concentration (LOL). Quality losses related to anaerobic condition increase when fruit are stored under LOL. Ideally, fruit should be stored at levels just above the critical $\mathrm{O}_{2}$ concentration (Gasser et al. 2008). It has been reported that fruit kept in these conditions could be stored for a long time without significant losses (Prange et al. 2007; Zanella et al. 2008; Wright et al. 
2012). Researches in some apple varieties showed that DCA is more effective than CA for maintaining quality during storage (Veltman et al. 2003; Gasser et al. 2005; Delong et al. 2007; Bessemans et al. 2016; Thewes et al. 2017).

DCA technology involves monitoring of gas concentrations in the storage room via sensors. Up to now, three sensors has been developed in this technology; chlorophyll fluorescence (CF), respiration quotient (RQ) and ethanol (ET) (Thewes et al. 2018). While very little research has been done with RQ and ET sensors, CF is the most common used sensor in the pome fruit industry (Mditshwa et al. 2018).

$\mathrm{CF}$ technique measures the stress occurring in fruit during storage period. In this method, while the $\mathrm{O}_{2}$ level is reduced, the CF signal on the fruit surface is measured by the sensor (Vanoli et al. 2010). Detection technology senses the response from the produce and feeds it back to an analytical software tool (HarvestWatch ${ }^{\mathrm{TM}}$ ) where the output is displayed in graph format (Stephens \& Tanner 2005). The increase in the fluorescence signal indicates that the product enters low $\mathrm{O}_{2}$ stress (Watkins 2008). The $\mathrm{O}_{2}$ level is maintained over the LOL level by adapting according to fruit metabolism during storage.

In researches on effect of CA, ULO and DCA storage conditions for maintaining significant quality criteria in apples, results has changed based on cultivars (Aubert et al. 2015; Both et al. 2017; Kittemann et al. 2015; Thewes et al. 2015; Tran et al. 2015; Brizzolara et al. 2017). Therefore, in this study, the effects of CA, ULO and DCA on fruit quality of 'Scarlet Spur' apple cultivar was evaluated during a storage period of 10 months plus a shelf life period of 7 days at $20^{\circ} \mathrm{C}$.

\section{Material and Methods}

\subsection{Plant material}

Experimental fruit were obtained from the commercial apple orchard located in Isparta/Eğirdir ( $38^{\circ} 17^{\prime} \mathrm{North}^{\prime}, 30^{\circ} 55^{\prime}$ East), in 2012. The uniform trees were 8 years old cv. 'Scarlet Spur' apple on MM106 rootstock. Standard cultural practices were applied to the trees during fruit growth and development period.

\subsection{Fruit harvest and storage conditions}

Fruit were harvested at commercial harvest stage and transported to the postharvest physiology laboratory. Apples were randomly divided into three groups and stored at $0{ }^{\circ} \mathrm{C}$ and $90 \pm 5 \%$ relative humidity $(\mathrm{RH})$ during 10 months in $\mathrm{CA}\left(\mathrm{CO}_{2} 4 \%\right.$, $\left.\mathrm{O}_{2} 3 \%\right)$, ULO $\left(\mathrm{CO}_{2} 3 \%, \mathrm{O}_{2} 1 \%\right.$,) or DCA $\left(0.5 \% \mathrm{O}_{2}\right.$ and $\left.1 \% \mathrm{CO}_{2}\right)$ conditions, respectively. Cabinets manufactured with gas tight plastic material and each was $0.5 \mathrm{~m}^{3}$ volume. HarvestWatch ${ }^{\mathrm{TM}}$ was used to assess lower $\mathrm{O}_{2}$ limit (LOL) of fruit during DCA storage. LOL stress in fruit under DCA was assessed by CF sensors placed over a sample of 6 fruit each batch. LOL level in DCA was determined as $0.2 \%$. The samples were stored at $0.5 \% \mathrm{O}_{2}$ level by adding $0.3 \%$ safety margin to the determined LOL level under DCA conditions. After cold storage, apples were kept at $20{ }^{\circ} \mathrm{C}$ and $60 \pm 5 \% \mathrm{RH}$ for 7 days to determine the effects of treatments on some quality parameters investigated in this research during shelf life.

\subsection{Respiration rate and ethylene production}

Fruit $(1 \mathrm{~kg})$ were kept in $5 \mathrm{~L}$ airtight jars at room condition $\left(20^{\circ} \mathrm{C}\right)$ for determination of ethylene emission and respiration rate. After $3 \mathrm{~h}$, the gas sample was taken from the closed jars by a gastight syringe and injected into loop of gas chromatography (GC) (Agilent 6840). Ethylene emission and respiration rate were measured by GC equipped with flame ionization (FID) and thermal conductivity detectors (TCD), respectively. Measurements were made in split/splitless (S/SL) of inlet in split mode with gas sampling valve with 1-mL gas sample by using fused silica capillar column (GS-GASPRO, $30 \mathrm{~m}$ x $0.32 \mathrm{~mm}$ I.D., U.S.A). Results were calculated as $\mu \mathrm{L} \mathrm{kg}^{-1} \mathrm{~h}^{-1}$ and $\mathrm{ml} \mathrm{CO}_{2} \mathrm{~kg}^{-1} \mathrm{~h}^{-1}$ for ethylene production and respiration rate, respectively.

\subsection{Fruit flesh firmness}

Fruit flesh firmness was measured by using a texture analyzer (Güss FTA Type GS14 Fruit-Texture Analyzer Model, Strand, South Africa). The measurements were performed on both side of apple after skin removal using a stainless probe (11.1 mm). Firmness was measured over 10 fruit in each replication and results were presented in Newton (N).

\subsection{Soluble solids content (SSC) and titratable acidity (TA)}

The fruit juice from 10 apples in each replication was extracted with the help of a juicer for analysis. The soluble solids content (SSC) of apple juice (\%) was determined with a refractometer (Digital-Atago Pocket PAL-1). The titratable acidity (TA) in apple juice was measured by titration of $10 \mathrm{~mL}$ of juice with $\mathrm{NaOH}$ solution $\left(0.1 \mathrm{~mol} \mathrm{~L}^{-1}\right)$ to an end-point $\mathrm{pH}$ of $8.1 \mathrm{by}$ a $\mathrm{pH}$ meter (Hanna pH 330 model, WTW, Germany). The results were expressed as \% malic acid. 


\subsection{Fruit skin color}

Fruit skin color of apples was measured with a colorimeter (Minolta CR 400, USA). Color measurements were made on both sides of 10 fruit in each replication along the equatorial axes. The calibration of color measurement apparatus was performed using an original calibration plate (white). The fruit colors were evaluated as CIE L*, $a^{*}$ and $b^{*}$.

\subsection{Weight loss}

Weight loss of fruit was measured based on the initial weight and calculated as percent (weight loss \% $=[($ first weight - last weight)/ first weight $\times 100)$ ] during cold storage. In order to measure the weight loss during the shelf life period, weight measurements were made at the beginning and at the end of the shelf life. Weight loss of apples was measured over 10 fruit in each replicate.

\subsection{Statistical analysis of results}

The completely randomized design (with three replications) was chosen for this experiment. Using software package (JMP7), the general linear model was used for statistical analyses. The differences among means (at a significance level of 0.05) were analyzed using LSD test.

\section{Results and Discussion}

\subsection{Respiration rate and ethylene production}

During storage and shelf life, respiration rate increased in all storage conditions (Figure1). The differences between conditions and periods and their interactions were statistically significant in both cold storage and room conditions $(\mathrm{P}<0.001,0.0001)$. The highest respiration rate during storage was determined in samples in CA (mean $9.87 \mathrm{~mL} . \mathrm{CO} 2 \mathrm{~kg}^{-1} \mathrm{~h}^{-1}$ ) while the lowest respiration rate was observed in DCA (mean $7.22 \mathrm{~mL} . \mathrm{CO}_{2} \mathrm{~kg}^{-1} \mathrm{~h}^{-1}$ ). DCA was the best storage condition to suppress respiration rate. In room conditions, respiration rate values obtained from samples stored in ULO (11.86 mL.CO $\left.\mathrm{kg}^{-1} \mathrm{~h}^{-1}\right) \mathrm{and} \mathrm{DCA}(11.39$ mL.CO $\left.\mathrm{CO}_{2} \mathrm{~kg}^{-1}\right)$ gave similar results. CA conditions were again resulted the highest $\left(14.93 \mathrm{~mL} . \mathrm{CO}_{2} \mathrm{~kg}^{-1} \mathrm{~h}^{-1}\right)$ respiration rate. It was determined that DCA storage of 'Granny Smith' apple suppressed respiratory rate better than CA storage (Eren et al. 2015). Similarly, previous studies have showed that limiting $\mathrm{O}_{2}$ levels, significantly reduces respiration rate (Gasser et al. 2008; Wright et al. 2012; Thewes et al. 2015). Respiration is the breakdown of complex molecules (starch, sugar and organic acids) to simple molecules $\left(\mathrm{CO}_{2}\right.$ and $\left.\mathrm{H}_{2} \mathrm{O}\right)$ in the cell (Kader 2002). In the final stage of the respiratory reaction; as $\mathrm{O}_{2}$ acts as the ultimate electron acceptor in the mitochondrial electron transport chain, the metabolism of the fruit can be slowed down by lowering the $\mathrm{O}_{2}$ concentration in the storage (Bekele et al. 2016).

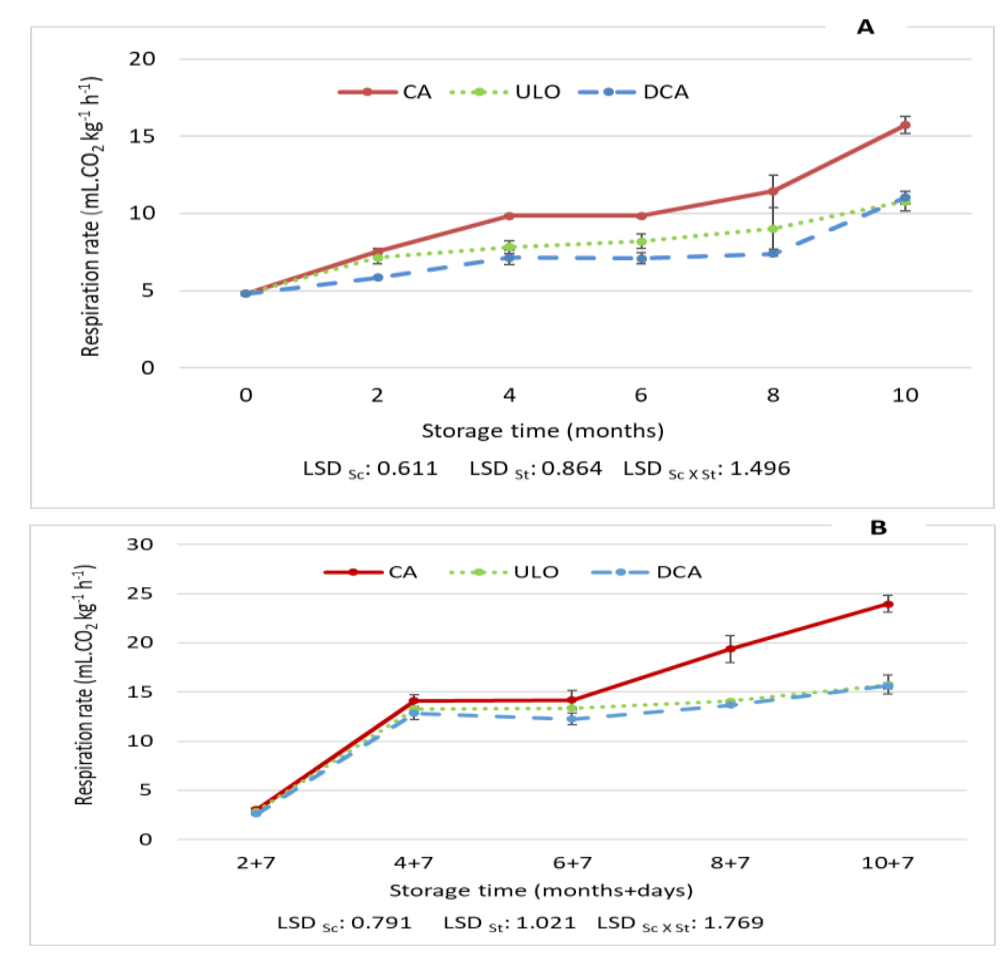

Figure 1- Respiration rate of 'Scarlet Spur' apples stored under different atmosphere conditions during 10 months (A) and plus 7 days for shelf life $(B)$. Vertical bars represent standard error $(n=3)$ 
The effects of storage conditions and periods on ethylene production were statistically significant. The interaction between time and condition was also significant $(\mathrm{P}<0.05,0.0001)$. During cold storage and shelf life, the amount of ethylene production increased in all three storage conditions (Figure 2). The highest increase was observed in CA storage. In the $8^{\text {th }}$ month of storage, the ethylene production in the CA $\left(7.46 \mu \mathrm{L} . \mathrm{C}_{2} \mathrm{H}_{4} \mathrm{~kg}^{-1} \mathrm{~h}^{-1}\right)$ showed a noteworthy increase compared to other conditions. This rapid increase in shelf life began to be observed since the $4^{\text {th }}$ month $\left(41.32 \mu \mathrm{L}_{2} \mathrm{C}_{2} \mathrm{H}_{4} \mathrm{~kg}^{-1} \mathrm{~h}^{-1}\right)$. The highest average ethylene production during storage was obtained under CA storage. ULO and DCA caused in similar results in terms of ethylene production. For some apple cultivars, higher ethylene production was found in fruit stored in CA conditions compared to fruit stored in ULO and DCA conditions (Mattheis et al. 1998; Hennecke et al. 2008; Çalhan et al. 2012; Thewes et al. 2015). Since ethylene initiates the ripening process in fruit, its production is reduced to the lowest possible level, resulting in higher fruit quality after storage. (Watkins 2006).

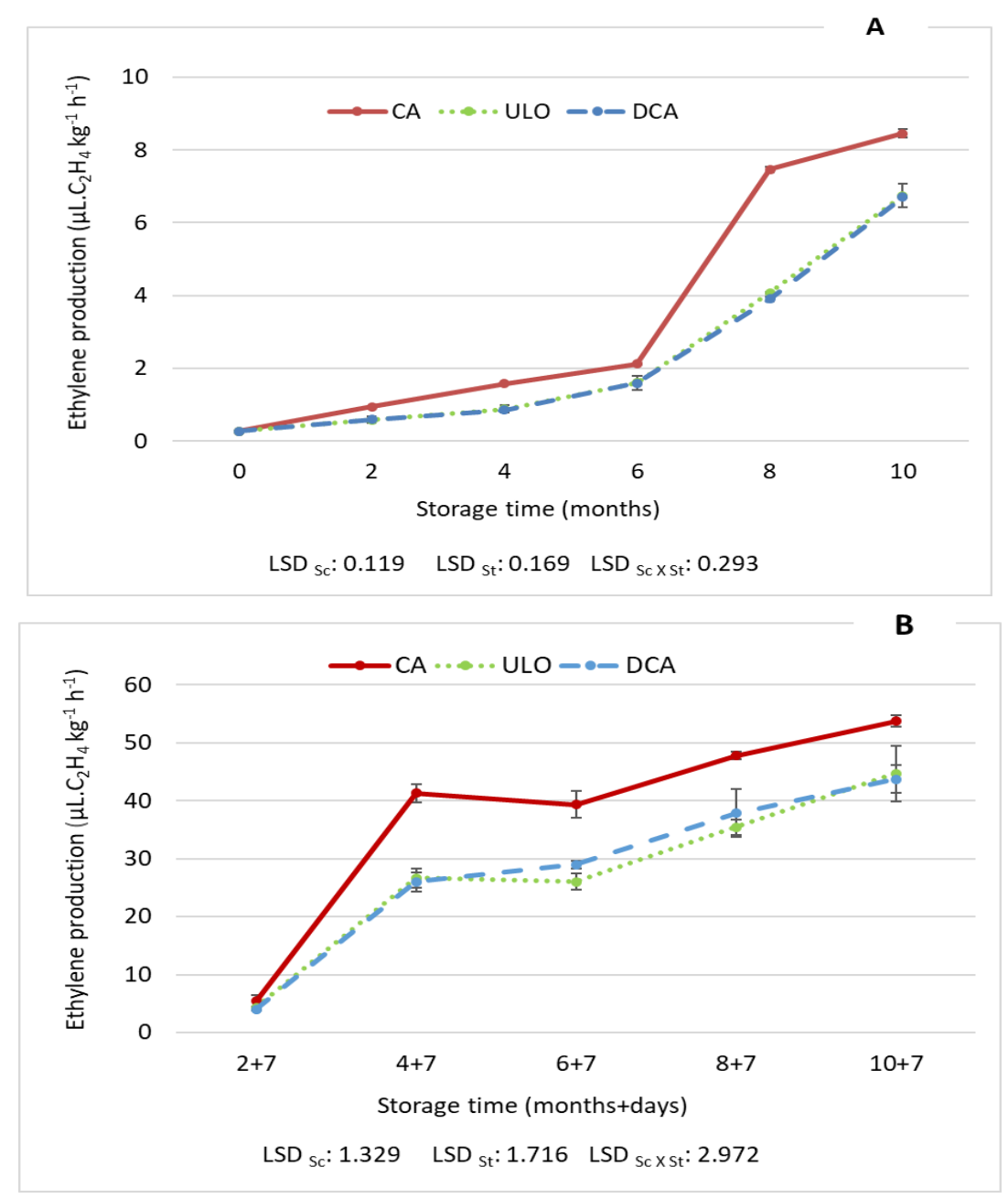

Figure 2- Ethylene production of 'Scarlet Spur' apples stored under different atmosphere conditions during 10 months (A) and plus 7 days for shelf life (B). Vertical bars represent standard error $(n=3)$

Reducing $\mathrm{O}_{2}$ level in the storage atmosphere decreases the ethylene production of fruit (Gorny \& Kader 1996). Storage of apples under DCA conditions significantly reduces ethylene synthesis and maintains long-term quality parameters (Watkins, 2008). DCA storage is effective in suppressing the activity of 1-Aminocyclopropane-1-carboxylate (ACC) oxidase enzyme that plays a key role in ethylene synthesis and production (Thewes et al. 2015; Weber et al. 2015; Thewes et al. 2017). ACC formed during ethylene synthesis pathway is oxidized by ACC oxidase enzyme and convert to ethylene (Nath et al. 2006). Therefore, reduction of $\mathrm{O}_{2}$ in the storage room inhibits the activity of ACC oxidase enzyme and the conversion of ACC to ethylene.

\subsection{Firmness (N), SSC (\%) and TA (\%)}

According to the changes in fruit firmness values, the differences between the storage conditions and the storage period were statistically significant $(\mathrm{P}<0.0001)$. With the prolonged storage period, the firmness values of the samples decreased in all conditions. Firmness, which is one of the most important factors affecting apple quality, decreases in relation to water loss during long term cold storage (Mditshwa et al. 2017b). This decrease in the value of firmness during storage has been shown similarly in previous studies (Koyuncu \& Bayındır 2013). Gwanpua et al. (2014) reported that the loss of sugar in the 
'Jonagold' apples during ripening, increased pectin solubility, and the decrease in the water-soluble pectin molar mass were caused by softening. The highest average fruit flesh firmness values were obtained from the samples stored in DCA and ULO conditions during the storage $(68.11 \mathrm{~N}-67.56 \mathrm{~N})$ and shelf life $(54.50 \mathrm{~N}-52.28 \mathrm{~N})$ period. (Table 1, 2). Fruit flesh firmness was better protected in low $\mathrm{O}_{2}$ conditions (De Castro et al. 2007). During the maturation, some enzymes cause the polymerization of pectin polymers and loosening the cohesion between the cells (Brummell \& Harpster, 2001; Goulao \& Oliveira 2008). This loss in cohesion of the pectin network is responsible for softening (Fischer \& Bennett 1991). Many enzymes play a role in cell wall modifications during maturation of apples. The activities of these enzymes are related to ethylene production (Gwanpua et al. 2014). Ethylene signals the cell wall degrading enzymes and triggers their activity (Payasi et al. 2009). The lower firmness loss in DCA is related to the low amount of ethylene produced in this condition. It is reported that DCA storage suppresses the enzymes responsible for softening (Mditshwa et al. 2018). Studies on apples have shown that the firmness of fruit flesh in DCA conditions is better protected than CA conditions (Mattheis et al. 1998; Zanella et al. 2005; DeLong et al. 2007; Zanella et al. 2008; Tran et al. 2015; Thewes et al. 2015 Bessemans et al. 2016; Mditshwa et al. 2017a). The ULO conditions also yielded better results than CA storage in maintaining firmness. Similar findings were obtained from previous studies on 'Royal Gala' apple variety (Thewes et al. 2015; Weber et al. 2015; Both et al. 2017).

Table 1- Firmness (N), SSC (\%) and TA (\% malic acid) of 'Scarlet Spur' apples during cold storage

\begin{tabular}{|c|c|c|c|c|c|c|c|c|}
\hline \multirow{2}{*}{\multicolumn{2}{|c|}{$\begin{array}{c}\text { Storage conditions } \\
(\mathrm{Sc})\end{array}$}} & \multicolumn{6}{|c|}{ Storage time $(S t)$} & \multirow[t]{2}{*}{ Mean } \\
\hline & & 0 & 2 & 4 & 6 & 8 & 10 & \\
\hline \multirow{4}{*}{$\begin{array}{l}\text { Firmness } \\
\text { (N) }\end{array}$} & CA & 76.60 & 64.84 & 62.81 & 60.21 & 55.25 & 47.76 & $61.25 \mathrm{~B}^{1}$ \\
\hline & ULO & 76.60 & 72.47 & 68.12 & 66.35 & 62.54 & 59.30 & $67.56 \mathrm{~A}$ \\
\hline & DCA & 76.60 & 71.46 & 70.18 & 66.16 & 65.18 & 59.08 & $68.11 \mathrm{~A}$ \\
\hline & Mean & $76.60 \mathrm{a}$ & $69.59 b$ & $67.03 \mathrm{c}$ & $64.24 d$ & $60.99 \mathrm{e}$ & $55.38 f$ & \\
\hline \multirow[t]{3}{*}{$P$ values } & & $\mathrm{Sc} * * *$ & St $* * *$ & Sc X St * & & & & \\
\hline & $\mathbf{C A}$ & 12.57 & 14.70 & 15.60 & 15.80 & 15.27 & 15.93 & $14.98^{\mathrm{NS}}$ \\
\hline & ULO & 12.57 & 15.30 & 15.33 & 15.70 & 14.97 & 15.70 & 14.93 \\
\hline \multirow[t]{2}{*}{$\operatorname{SSC}(\%)$} & DCA & 12.57 & 15.00 & 15.23 & 15.63 & 15.73 & 15.57 & 14.96 \\
\hline & Mean & $12.57 \mathrm{NS}$ & 15.00 & 15.39 & 15.71 & 15.32 & 15.73 & \\
\hline \multirow[t]{2}{*}{$P$ values } & & $\mathrm{Sc} N S$ & St NS & Sc X St NS & & & & \\
\hline & $\mathbf{C A}$ & 0.36 & 0.33 & 0.30 & 0.29 & 0.27 & 0.23 & $0.30 \mathrm{~B}$ \\
\hline \multirow[t]{3}{*}{ TA (\% malic acid) } & ULO & 0.36 & 0.33 & 0.31 & 0.31 & 0.30 & 0.26 & $0.31 \mathrm{~A}$ \\
\hline & DCA & 0.36 & 0.33 & 0.31 & 0.30 & 0.29 & 0.27 & $0.31 \mathrm{~A}$ \\
\hline & Mean & $0.36 \mathrm{a}$ & $0.33 b$ & $0.31 \mathrm{c}$ & $0.30 \mathrm{c}$ & $0.29 \mathrm{~cd}$ & $0.25 \mathrm{e}$ & \\
\hline$P$ values & & $\mathrm{Sc} * * *$ & $\mathrm{St} * * *$ & Sc X St NS & & & & \\
\hline
\end{tabular}

*, $\mathrm{P}<0.05-0.01 ; * *, \mathrm{P}<0.01-0.001 ; * * *, \mathrm{P}<0.0001$; NS, nonsignificant. ${ }^{1}$ Means followed by different letters with in the same row and column are significantly different.

Table 2- Firmness (N), SSC (\%) and TA (\%) of 'Scarlet Spur' apples during shelf life after cold storage

\begin{tabular}{|c|c|c|c|c|c|c|c|}
\hline \multirow{2}{*}{\multicolumn{2}{|c|}{$\begin{array}{c}\text { Storage conditions } \\
(\mathrm{Sc})\end{array}$}} & \multicolumn{5}{|c|}{ Storage time $(S t)$} & \multirow[t]{2}{*}{ Mean } \\
\hline & & $2+7$ & $4+7$ & $6+7$ & $8+7$ & $10+7$ & \\
\hline \multirow{4}{*}{$\begin{array}{l}\text { Firmness } \\
\text { (N) }\end{array}$} & $\mathrm{CA}$ & 45.03 & 52.65 & 50.13 & 37.26 & 24.92 & $42.00 \mathrm{~B}^{1}$ \\
\hline & ULO & 55.58 & 63.40 & 56.30 & 44.84 & 41.27 & $52.28 \mathrm{~A}$ \\
\hline & DCA & 62.38 & 56.43 & 62.41 & 52.03 & 39.26 & $54.50 \mathrm{~A}$ \\
\hline & Mean & $54.33 \mathrm{~cd}$ & $57.49 a$ & $56.28 \mathrm{~b}$ & $44.71 d$ & $35.15 \mathrm{e}$ & \\
\hline \multirow[t]{3}{*}{$P$ values } & $\mathrm{Sc} * * *$ & St $* * *$ & Sc X St * & & & & \\
\hline & CA & 16.03 & 15.47 & 15.40 & 16.33 & 16.73 & $15.99^{\mathrm{NS}}$ \\
\hline & ULO & 15.83 & 15.67 & 16.20 & 15.30 & 15.80 & 15.76 \\
\hline \multirow[t]{2}{*}{$\operatorname{SSC}(\%)$} & DCA & 15.03 & 15.63 & 15.93 & 15.13 & 15.67 & 15.48 \\
\hline & Mean & $15.63^{\mathrm{NS}}$ & 15.59 & 15.84 & 15.59 & 16.07 & \\
\hline \multirow[t]{2}{*}{$P$ values } & Sc NS & St NS & Sc X St NS & & & & \\
\hline & CA & 0.28 & 0.24 & 0.25 & 0.21 & 0.17 & $0.23 \mathrm{~B}$ \\
\hline \multirow[t]{3}{*}{ TA $(\%)$} & ULO & 0.32 & 0.28 & 0.27 & 0.25 & 0.23 & $0.27 \mathrm{~A}$ \\
\hline & DCA & 0.31 & 0.31 & 0.30 & 0.25 & 0.22 & $0.28 \mathrm{~A}$ \\
\hline & Mean & $0.30 \mathrm{a}$ & $0.28 b$ & $0.27 b$ & $0.24 \mathrm{c}$ & $0.20 \mathrm{~d}$ & \\
\hline$P$ values & $\mathrm{Sc} * * *$ & St $* * *$ & Sc X St NS & & & & \\
\hline
\end{tabular}

*, $\mathrm{P}<0.05-0.01$; **, $\mathrm{P}<0.01-0.001 ; * * *, \mathrm{P}<0.0001$; NS, nonsignificant. ${ }^{1}$ Means followed by different letters with in the same row and column are significantly different.

In comparison with the DCA and ULO conditions in terms of fruit flesh firmness, it is better protected in the apple cultivars of 'Gloster' (Köpcke 2015), 'Granny Smith' and 'Red Delicious' (Mditshwa et al. 2017a, 2017b; Brizzolara et al. 2017) in the DCA conditions while similar results obtained from the studies regarding apple cultivars 'Golden Delicious' and 'Pinova' (Kittemann et al. 2015), 'Fuji' and 'Gala' (Zanella \& Rossi 2015). This is mainly because of different metabolic reactions of apple genotypes (Brizzolara et al. 2017). 
The SSC of fruit increased at the end of the storage period compared to initial values with fluctuation during cold storage. The amount of SSC was $12.57 \%$ at harvest. At the end of the cold storage period, SSC amount was determined as $15.93 \%$ in CA, $15.70 \%$ in ULO and $15.57 \%$ in DCA condition. No significant difference was observed between technologies in terms of SSC (Table 3, 4). TA values decreased significantly during cold storage and shelf life (Table 3, 4). The decrease of TA during storage is due to the consumption of malic acid as a metabolite substrate in fruit respiration (Ackerman et al. 1992). TA was significantly lower in samples stored in CA compared to other conditions $(\mathrm{P}<0.0001)$. The ULO and DCA conditions showed similar results in the maintenance of TA amount. Similarly, 'Granny Smith' (Eren et al. 2015), 'Cortland' (DeLong et al. 2007), 'Royal Gala' (Weber et al. 2015), and 'Red Delicious' (Brizzolara et al. 2017) apple cultivars have been reported to maintain better TA levels under the DCA and ULO than CA conditions. The CA conditions with low $\mathrm{O}_{2}$ are advantageous in maintaining TA values (Özer 2002). Generally, a decrease in the concentration of $\mathrm{O}_{2}$ in atmosphere causes a decrease in consumption rates of citrate and malate in the formation of organic acids in the tricarboxylic acid cycle (Mir \& Beaudry 2002).

Table 3- Fruit skin color changes of 'Scarlet Spur' apples during storage and shelf life

\begin{tabular}{|c|c|c|c|c|c|c|c|c|}
\hline \multirow{2}{*}{\multicolumn{2}{|c|}{$\begin{array}{c}\text { Storage conditions } \\
(\mathrm{Sc})\end{array}$}} & \multicolumn{7}{|c|}{ Storage time $($ St)(months) } \\
\hline & & 0 & 2 & 4 & 6 & 8 & 10 & Mean \\
\hline & CA & 30.53 & 30.66 & 29.64 & 29.59 & 27.02 & 27.21 & $29.11 \mathrm{~A}^{1}$ \\
\hline \multirow[t]{3}{*}{$\mathbf{L}^{*}$} & ULO & 29.71 & 29.74 & 27.89 & 28.60 & 25.07 & 26.50 & $27.92 \mathrm{~B}$ \\
\hline & DCA & 29.93 & 30.43 & 28.88 & 28.56 & 25.49 & 25.38 & $28.11 \mathrm{~B}$ \\
\hline & Mean & $30.06 \mathrm{a}$ & $30.28 \mathrm{a}$ & $28.80 \mathrm{~b}$ & $28.92 b$ & $25.86 \mathrm{c}$ & $26.36 \mathrm{c}$ & \\
\hline \multirow[t]{3}{*}{$P$ values } & $\mathrm{Sc} * * *$ & $\mathrm{St}^{* * *}$ & Sc X St & NS & & & & \\
\hline & CA & 19.14 & 20.80 & 23.31 & 23.21 & 24.66 & 23.52 & $22.44 \mathrm{~A}$ \\
\hline & ULO & 19.10 & 20.12 & 22.81 & 22.53 & 24.81 & 24.68 & $22.34 \mathrm{~A}$ \\
\hline \multirow[t]{2}{*}{$a^{*}$} & DCA & 18.44 & 19.63 & 21.72 & 21.68 & 23.53 & 23.40 & $21.40 \mathrm{~B}$ \\
\hline & Mean & $18.89 \mathrm{e}$ & $20.18 d$ & $22.62 b c$ & $22.47 \mathrm{c}$ & $24.33 \mathrm{a}$ & $23.87 \mathrm{ab}$ & \\
\hline \multirow[t]{2}{*}{$P$ values } & $\mathrm{Sc}^{*}$ & $\mathrm{St}^{* * *}$ & Sc X St & NS & & & & \\
\hline & $\mathbf{C A}$ & 8.98 & 9.90 & 11.06 & 10.94 & 11.54 & 11.63 & $10.68 \mathrm{~A}$ \\
\hline \multirow[t]{3}{*}{$\mathbf{b}^{*}$} & ULO & 8.44 & 9.13 & 10.22 & 10.20 & 11.21 & 11.69 & $10.15 \mathrm{AB}$ \\
\hline & DCA & 8.33 & 9.12 & 9.99 & 9.80 & 10.51 & 10.65 & $9.73 \mathrm{~B}$ \\
\hline & Mean & $8.58 \mathrm{c}$ & $9.38 \mathrm{c}$ & $10.42 \mathrm{ab}$ & $10.32 b$ & 11.08ab & $11.32 \mathrm{a}$ & \\
\hline$P$ values & $\mathrm{Sc}^{*}$ & $\mathrm{St} * * *$ & Sc X St & NS & & & & \\
\hline \multirow{2}{*}{\multicolumn{2}{|c|}{$\begin{array}{c}\text { Storage conditions } \\
(\mathrm{Sc})\end{array}$}} & \multicolumn{7}{|c|}{ Storage time $($ St)(months + days) } \\
\hline & & & $2+7$ & $4+7$ & $6+7$ & $8+7$ & $10+7$ & Mean \\
\hline \multirow{4}{*}{$\mathbf{L}^{*}$} & CA & & 33.97 & 30.72 & 33.27 & 34.78 & 33.02 & $33.15^{\mathrm{NS}}$ \\
\hline & ULO & & 32.37 & 30.63 & 31.70 & 33.07 & 32.70 & 32.10 \\
\hline & DCA & & 32.66 & 29.15 & 32.39 & 34.41 & 31.03 & 31.93 \\
\hline & Mean & & $33.00 \mathrm{~b}$ & $30.17 \mathrm{~d}$ & $32.46 \mathrm{bc}$ & $34.08 \mathrm{a}$ & $32.25 \mathrm{c}$ & \\
\hline \multirow[t]{3}{*}{$P$ values } & Sc NS & $\mathrm{St}^{* *}$ & Sc X St & NS & & & & \\
\hline & CA & & 25.01 & 23.65 & 23.10 & 25.33 & 22.52 & $23.92^{\mathrm{NS}}$ \\
\hline & ULO & & 24.35 & 23.26 & 24.01 & 21.99 & 22.05 & 23.13 \\
\hline \multirow[t]{2}{*}{$\mathbf{a}^{*}$} & DCA & & 24.22 & 23.86 & 23.09 & 24.33 & 22.16 & 23.53 \\
\hline & Mean & & $24.53^{\mathrm{NS}}$ & 23.59 & 23.40 & 23.88 & 22.24 & \\
\hline \multirow[t]{2}{*}{$P$ values } & Sc NS & St NS & Sc X St & NS & & & & \\
\hline & CA & & 13.61 & 12.33 & 11.56 & 12.46 & 10.81 & $12.16^{\mathrm{NS}}$ \\
\hline \multirow[t]{3}{*}{$\mathbf{b}^{*}$} & ULO & & 12.23 & 11.83 & 11.78 & 11.23 & 10.79 & 11.57 \\
\hline & DCA & & 11.51 & 11.26 & 11.41 & 10.77 & 10.57 & 11.10 \\
\hline & Mean & & $12.45^{\mathrm{NS}}$ & 11.81 & 11.58 & 11.49 & 10.72 & \\
\hline$P$ values & Sc NS & St NS & Sc X St & NS & & & & \\
\hline
\end{tabular}

*, $\mathrm{P}<0.05-0.01 ; * *, \mathrm{P}<0.01-0.001 ; * * *, \mathrm{P}<0.0001$; NS, nonsignificant. ${ }^{1}$ Means followed by different letters with in the same row and column are significantly different.

Table 4- Weight loss (\%) of 'Scarlet Spur' apples stored in different conditions

\begin{tabular}{|c|c|c|c|c|c|c|c|}
\hline \multirow{2}{*}{\multicolumn{2}{|c|}{$\begin{array}{c}\text { Storage conditions } \\
(\mathrm{Sc})\end{array}$}} & \multicolumn{5}{|c|}{ Storage time $(S t)$} & \multirow{2}{*}{ Mean } \\
\hline & & 2 & 4 & 6 & 8 & 10 & \\
\hline \multirow{4}{*}{ Cold Storage $\left(0^{\circ} \mathrm{C}\right)$} & $\mathbf{C A}$ & 0.44 & 0.85 & 1.21 & 1.51 & 2.08 & $1.22 \mathrm{~A}^{1}$ \\
\hline & ULO & 0.36 & 0.61 & 0.87 & 1.08 & 1.57 & $0.91 \mathrm{~B}$ \\
\hline & DCA & 0.36 & 0.63 & 0.88 & 1.07 & 1.61 & $0.90 \mathrm{~B}$ \\
\hline & Mean & $0.38 \mathrm{e}$ & $0.70 \mathrm{~d}$ & $0.99 \mathrm{c}$ & $1.22 \mathrm{~b}$ & $1.75 \mathrm{a}$ & \\
\hline \multirow{4}{*}{$\begin{array}{l}\text { Shelf Life } \\
\left(+7 \text { days at } 20^{\circ} \mathrm{C}\right)\end{array}$} & CA & 1.71 & 2.17 & 2.06 & 2.76 & 3.76 & $2.49 \mathrm{~A}$ \\
\hline & ULO & 1.57 & 1.83 & 1.69 & 2.16 & 2.82 & $2.02 \mathrm{~B}$ \\
\hline & DCA & 1.58 & 1.95 & 1.57 & 2.18 & 2.91 & $2.03 \mathrm{~B}$ \\
\hline & Mean & $1.62 \mathrm{e}$ & $1.98 \mathrm{c}$ & $1.77 \mathrm{~d}$ & $2.36 \mathrm{~b}$ & $3.16 \mathrm{a}$ & \\
\hline \multirow{3}{*}{$P$ values } & \multirow{3}{*}{ Cold Storage } & $\mathrm{Sc}$ & $* * *$ & \multirow{3}{*}{$\begin{array}{l}\text { Shelf } \\
\text { Life }\end{array}$} & $\mathrm{Sc}$ & $*$ & \\
\hline & & St & $* * *$ & & St & $* * *$ & \\
\hline & & Sc X St & $* * *$ & & Sc X St & NS & \\
\hline
\end{tabular}

*, $\mathrm{P}<0.05-0.01$; ***, $\mathrm{P}<0.0001$; NS, nonsignificant. ${ }^{1}$ Means followed by different letters with in the same row and column are significantly different. 


\subsection{Fruit skin color}

$\mathrm{L}^{*}$ value, which expresses brightness during storage and shelf life, generally decreased according to initial value. Whereas red color ( $\mathrm{a}^{*}$ ) and yellow ground color ( $\mathrm{b}^{*}$ ) increased due to maturation (Table 3 ). This increase is caused by the decomposition of chlorophyll forming the green color in the fruit during the storage and turning the color of the green in the fruit to yellow (Çalhan et al. 2012). The effect of different storage conditions on color values during storage was statistically significant $(\mathrm{P}<0.001)$. The interaction between the storage conditions and storage time was insignificant in both cold storage and shelflife conditions. The lowest average $\mathrm{a}^{*}$ and $\mathrm{b}^{*}$ values $(21.40-9.73)$ were obtained from the samples stored in DCA conditions during the storage period. DCA preserves the quality of fruit better, by contributing to the preservation of the fruit color during storage and shelf life (Zanella et al. 2008; Veltman et al. 2003). Previous studies showed that DCA technology gave better results in maintaining color of 'Granny Smith' than CA (Bessemans et al. 2016) and ULO in 'Elstar' (Veltman et al. 2003). Additionally, it was reported that DCA delays chlorophyll degradation (Tran et al. 2015).

\subsection{Weight Loss}

The weight loss during storage and shelf life of 'Scarlet Spur' apple samples kept under different atmospheric composition was increased continuously as shown in Table 4 . This change was statistically significant $(\mathrm{P}<0.0001)$. The maximum weight loss occurred in CA for both storage (1.22\%) and shelf life $(2.49 \%)$ period while the weight loss observed in ULO (0.91\%-2.02\%) and DCA $(0.90 \%-2.03 \%)$ conditions were similar. Weight loss is associated with the respiratory rate of the product. Increases in weight loss are due to the removal of water from the tissues along with the $\mathrm{CO}_{2}$ released as a result of the respiration of the product during storage (Erbaş et al. 2014). The gas composition in the ULO and DCA storage conditions suppressed the respiration rate better compared to the $\mathrm{CA}$ storage and thus the weight loss in these conditions was also lower. The interaction between storage time and storage conditions was statistically significant $(\mathrm{P}<0.0001)$ during storage and insignificant during shelf life.

\section{Conclusions}

Result of this study conducted with 'Scarlet Spur' apple showed that ULO and DCA conditions were more effective in maintaining quality compared to CA in terms of all quality parameters. DCA was the best storage condition suppressing respiration rate and ethylene production that expressed maturation during storage. Additionally, DCA was found to be more effective than other conditions to preserve important quality parameters in apple fruit such as color and firmness. As a result, the storage of 'Scarlet Spur' apples under DCA was found to be more successful than ULO and CA conditions in terms of preservation of quality criteria in long-term cold storage and during shelf life.

\section{Acknowledgements}

This research was a part of $\mathrm{PhD}$ thesis and supported by Süleyman Demirel University Scientific Research Support Unit (Project No: 3258-D2-12) and General Directorate of Agricultural Research and Policies (Project No: BBMB-11-02).

\section{References}

Ackerman J, Fisher M \& Amado R (1992). Changes in sugars, acids, amino acids during ripening and storage of apples (cv. Glockenapfel). Journal of Agricultural Food Chemistry 40:1131-1134 https://doi.org/10.1021/jf00019a008

Aubert C, Mathieu-Hurtiger V \& Vaysse P (2015). Effects of dynamic atmosphere on volatile compounds, polyphenolic content, overall fruit quality, and sensory evaluation of pink lady ${ }^{\circledR}$ apples. Acta Horticulturae 1071, pp. 275-280 https://doi.org/10.17660/actahortic.2015.1071.34

Balla B \& Holb I (2007). Effect of three storage methods on fruit decay and brown rot of apple. International of Horticultural Science 13(3): 55-57 https://doi.org/10.31421/ijhs/13/3/746

Batu A \& Sen L (2014). Controlled atmosphere storage technology and its application. Electronic Journal of Food Technologies 9(3): 118138

Bekele E A, Ampofo-Asiama J, Alis R R, Hertog M, Nicolai B M \& Geeraerd A H (2016). Dynamics of metabolic adaptation during initiation of controlled atmosphere storage of 'Jonagold' apple: Effects of storage gas concentrations and conditioning. Postharvest Biology and Technology 117: 9-20 https://doi.org/10.1016/j.postharvbio.2016.02.003

Bertone E, Venturello A, Leardi R, Geobaldo F (2012). Prediction of the optimum harvest time of 'Scarlet' apples using DR-UV-Vis and NIR spectroscopy. Postharvest Biology and Technology 69: 15-23 https://doi.org/10.1016/j.postharvbio.2012.02.009

Bessemans N, Verboven P, Verlinden B \& Nicolaï B (2016). A novel type of dynamic controlled atmosphere storage based on the respiratory quotient (RQ-DCA). Postharvest Biology and Technology 115: 91-102 https://doi.org/10.1016/j.postharvbio.2015.12.019

Both V, Brackmann A, Thewes F R, Freitas Ferreira D \& Wagner R (2014). Effect of storage under extremely low oxygen on the volatile composition of 'Royal Gala' apples. Food Chemistry 156: 50-57 https://doi.org/10.1016/j.foodchem.2014.01.094

Both V, Thewes F R, Brackmann A, de Oliveira Anese A, de Freitas Ferreira D \& Wagner R (2017). Effects of dynamic controlled atmosphere by respiratory quotient on some quality parameters and volatile profile of 'Royal Gala' apple after long-term storage. Food Chemistry 215: 483-492 https://doi.org/10.1016/j.foodchem.2016.08.009 
Brizzolara S, Santucci C, Tenori L, Hertog M, Nicolai B, Stürz S \& Tonutti P (2017). A metabolomics approach to elucidate apple fruit responses to static and dynamic controlled atmosphere storage. Postharvest Biology and Technology 127: 76-87 https://doi.org/10.1016/j.postharvbio.2017.01.008

Brummell D A \& Harpster M H (2001). Cell wall metabolism in fruit softening and quality and its manipulation in transgenic plants. Plant Molecular Biology 47: 311-340 https://doi.org/10.1007/978-94-010-0668-2_18

Çalhan Ö, Eren I, Onursal C E \& Güneyli A (2012). The effects of DCA storage on "Granny Smith" apple. V. Preservation and Marketing Symposium on Horticultural Products 18-21 September, İzmir, pp.145-152 (In Turkish)

De Castro E, Biasi W V \& Mitcham E J (2007). Quality of Pink Lady Apples in relation to maturity at harvest, prestorage treatments, and controlled atmosphere during storage. HortScience 42: 605-610 https://doi.org/10.21273/hortsci.42.3.605

DeLong J M, Prange R K \& Harrison P A (2007). Chlorophyll-fluorescence based low-O $\mathrm{O}_{2}$ CA storage of organic 'Cortland' and 'Delicious' apples. Acta Horticulturae 737: 31-37 https://doi.org/10.17660/actahortic.2007.737.3

Erbaş D, Onursal C E, Babalık Z \& Koyuncu M A (2014). The use of salicylic acid in cold storage of table grapes. VI. Preservation and

Marketing Symposium on Horticultural Products, 22-25 September 2014, Bursa, pp. 22-31 (In Turkish)

Eren I, Çalhan Ö, Onursal C E \& Güneyli A (2015). Effect of controlled atmosphere,dynamic controlled atmosphere and 1-MCP on quality of 'Granny Smith' apples. Acta Horticulturae 1071: 495-502 https://doi.org/10.17660/actahortic.2015.1071.64

Fischer R L \& Bennett A B (1991). Role of cell wall hydrolases in fruit ripening. Annual Review of Plant Physiology and Plant Molecular Biology 42: 675-703 https://doi.org/10.1146/annurev.pp.42.060191.003331

Gasser F, Dätwyler D, Schneider K, Naunheim W \& Hoehn E (2005). Effects of decreasing oxygen levels in the storage atmosphere on the respiration and production of volatiles of Idared apples. Acta Horticulturae 682: 1585-1592 https://doi.org/10.17660/actahortic.2003.600.23

Gasser F, Eppler T, Naunheim W, Gabioud S \& Hoehn E (2008). Control of the critical oxygen level during dynamic CA storage of apples by monitoring respiration as well as chlorophyll fluorescence. Acta Horticulturae 796:69-76 https://doi.org/10.17660/actahortic.2008.796.6

Gorny J R \& Kader A A (1996). Regulation of ethylene biosynthesis in climacteric apple fruit by elevated $\mathrm{CO}_{2}$ and reduced $\mathrm{O}_{2}$ atmospheres. Postharvest Biology and Technology 9: 311-323 https://doi.org/10.1016/s0925-5214(96)00040-3

Goulao L F \& Oliveira C M (2008). Cell wall modifications during fruit ripening: When a fruit is not the fruit. Trends in Food Science \& Technology 19(1): 4-25 https://doi.org/10.1016/j.tifs.2007.07.002

Gwanpua S G, Van Buggenhout S, Verlinden B E, Christiaens S, Shpigelman A, Vicent V, Jamsazzadeh Kermani Z, Nicolai B M, Hendrickx M \& Geeraerd A (2014). Pectin modifications and the role of pectin-degrading enzymes during postharvest softening of Jonagold apples. Food Chemistry 158: 283-291 https://doi.org/10.1016/j.foodchem.2014.02.138

Hennecke C, Köpcke D \& Dierend W (2008). Dynamische Absenkung des Sauerstoffgehaltes bei der Lagerung von Äpfeln. ErwerbsObstbau 50: 19-29 https://doi.org/10.1007/s10341-007-0055-7

Kader A A (2002). Postharvest Biology and Technology: An overview. In: Kader A A (Ed), Postharvest Technology of Horticultural Crops, University of California Agricultural and Natural Resources Publication 3311, pp. 39-47

Kittemann D, McCormick R \& Neuwald D A (2015). Effect of high temperature and 1-MCP application or dynamic controlled atmosphere on energy savings during apple storage. European Journal of Horticultural Science 80(1): 33-38 https://doi.org/10.17660/ejhs.2015/80.1.5

Köpcke D (2015). 1-methylcyclopropene (1-MCP) and dynamic controlled atmosphere (DCA) applications under elevated storage temperatures: Effects on fruit quality of 'Elstar', 'Jonagold' and 'Gloster' apple (Malus domestica borkh.). European Journal of Horticultural Science 80: 25-32 https://doi.org/10.17660/ejhs.2015/80.1.4

Koyuncu M A \& Bayındır D (2013). Air and controlled atmosphere of Scarlet Spur apple cultivar. Anadolu Journal of Agricultural Science 28(2): 71-76 (In Turkish) https://doi.org/10.7161/anajas.2013.282.71

Mattè P, Buglia L, Boschetti A, Fadanelli L, Chistè C \& Zeni F (2005). ILOS + ULO as a practical technology for apple scald prevention. Acta Horticulturae 682: 1543-1550 https://doi.org/10.17660/actahortic.2005.682.205

Mattheis J, Buchanan D \& Fellman J (1998). Volatile compounds emitted by 'Gala' apples following dynamic atmosphere storage. Journal of the American Society for Horticultural Science 123: 426-432 https://doi.org/10.21273/jashs.123.3.426

Mditshwa A, Fawole O A, Vries F, van der Merwe K, Crouch E \& Opara U L (2017a). Minimum exposure period for dynamic controlled atmospheres to control superficial scald in Granny Smith apples for long distance supply chains. Postharvest Biology and Technology 127: 27-34 https://doi.org/10.1016/j.postharvbio.2016.12.009

Mditshwa A, Fawole O A, Vries F, van der Merwe K, Crouch E \& Opara U L (2017b). Repeated application of dynamic controlled atmospheres reduced superficial scald incidence in 'Granny Smith' apples. Scientia Horticulturae 220: 168-175 https://doi.org/10.1016/j.scienta.2017.04.003

Mditshwa A, Fawole O A \& Opara U L (2018). Recent developments on dynamic controlled atmosphere storage of apples-A review. Food Packaging and Shelf Life 16: 59-68 https://doi.org/10.1016/j.fpsl.2018.01.011

Mir N \& Beaudry R (2002). Atmosphere Control Using Oxygen and Carbon Dioxide, Knee, M. (Ed), Fruit Quality and its Biological Basis, Sheffield Academic Press, ISBN 1-8127-230-2, UK, pp. 121-150

Nath P, Trivedi P K, Sane VA \& Sane A P (2006). Role of Ethylene in Fruit Ripening 151-184. Khan, NA (Ed.), Ethylene Action in Plants. ISBN-10 3-540-32716-9 Springer, Berlin Heidelberg New York.

Özer M H 2002. Controlled atmosphere (CA) storage of apple cv. Jonagold. Journal of Agricultural Faculty of Uludag 16(2):189-202 (In

Turkish)

Payasi A, Nath Mishra N, Soares Chaves A L \& Singh R (2009). Biochemistry of fruit softening: An overview. Physiology and Molecular Biology of Plants 15(2): 103-113 https://doi.org/10.1007/s12298-009-0012-z

Prange R K, DeLong J M, Harrison P, Mclean S, Scrutton J \& Cullen J (2007). Method and apparatus for monitoring a condition in chlorophyll containing matter. U.S. Patent, n.WO/2002/006795

Stephens B E \& Tanner D J (2005). The harvest watch system - measuring fruit's healthy glow. Acta Horticulturae 687: 363-364 https://doi.org/10.17660/actahortic.2005.687.49

Thewes F, Both, V, Brackmann A, Weber A \& de Oliveira Anese R (2015). Dynamic controlled atmosphere and ultralow oxygen storage on 'Gala' mutants quality maintenance. Food Chemistry 188: 62-70 https://doi.org/10.1016/j.foodchem.2015.04.128 
Thewes F R, Brackmann A, Both V, Weber A, de Oliveira Anese R, dos Santos Ferrão T \& Wagner R (2017). The different impacts of dynamic controlled atmosphere and controlled atmosphere storage in the quality attributes of 'Fuji Suprema' apples. Postharvest Biology and Technology 130: 7-20 https://doi.org/10.1016/j.postharvbio.2017.04.003

Thewes F R, Brackmann A, de Oliveira Anese R, Ludvig V, Schultz E E \& Pasquetti Berghetti M R (2018). 1-methylcyclopropene suppresses anaerobic metabolism in apples stored under dynamic controlled atmosphere monitored by respiratory quotient. Scientia Horticulturae 227: 288-295 https://doi.org/10.1016/j.scienta.2017.09.028

Thompson A K (2010). Controlled Atmosphere Storage of Fruits and Vegetables. CABI Publishing, London, UK

Tran D T, Verlinden B E, Hertog M \& Nicolai B M (2015). Monitoring of extremely low oxygen control atmosphere storage of 'Greenstar' apples using chlorophyll fluorescence. Scientia Horticulturae 184: 18-22 https://doi.org/10.1016/j.scienta.2014.11.014

Tuna Güneş N \& Horzum O (2017). Physiological events in horticultural crops. In: R Türk, N Tuna Güneş, M Erkan \& M A Koyuncu (Eds.), Storage and market preparation of horticultural products, Somtad Publications Textbook No: 1, Antalya/Türkiye, pp. $61-83$ (In Turkish)

Vanoli M, Eccher Zerbini P, Grassi M \& Rizzolo A (2010). Ethylene production and quality in 1-methylcyclopropene treated 'Abbé fétel' pears after storage in dynamically controlled atmosphere. Acta Horticulturae 876: 31-38 https://doi.org/10.17660/actahortic.2010.876.2

Veltman R, Verschoor J \& Van Dugteren J R (2003). Dynamic control system (DCS) for apples (Malus domestica Borkh. cv 'Elstar'): Optimal quality through storage based on product response. Postharvest Biology and Technology 27(1): 79-86 https://doi.org/10.1016/s0925-5214(02)00186-2

Watkins C B (2006). The use of 1-methylcyclopropene (1-MCP) on fruits and vegetables. Biotechnology Advances 24: 389-409 https://doi.org/10.1016/j.biotechadv.2006.01.005

Watkins C B (2008). Dynamic controlled atmosphere storage: A new technology for the New York storage industry. New York Fruit Quarterly 16(1): 23-26

Weber A, Brackmann A, Both V, Pavanello E P, Anese Rd O \& Thewes F R (2015). Respiratory quotient: Innovative method for monitoring Royal Gala apple storage in a dynamic controlled atmosphere. Scientia Agricola 72(1): 28-33 https://doi.org/10.1590/0103-9016-20130429

Wright A H, DeLong J M, Gunawardena A \& Prange R K (2012). Dynamic controlled atmosphere (DCA): Does fluorescence reflect physiology in storage? Postharvest Biology and Technology 64: 19-30 https://doi.org/10.1016/j.postharvbio.2011.09.015

Wright A, DeLong J, Arul J \& Prange R (2015). The trend toward lower oxygen levels during apple (Malus $\times$ domestica Borkh) storage. The Journal of Horticultural Science and Biotechnology 90(1): 1-13

Zanella A, Cazzanelli P, Panarese A, Coser M, Cecchinel M \& Rossi O (2005). Fruit fluorescence response to low-oxygen stress: modern storage technologies compared to 1-MCP treatment of apple. Acta Horticulturae 682:1535-1542 https://doi.org/10.17660/actahortic.2005.682.204

Zanella A, Cazzanelli P \& Rossi O (2008). Dynamic controlled atmosphere (DCA) storage by the means of chlorophyll fluorescence response for firmness retention in apple. Acta Horticulturae 796:77-82 https://doi.org/10.17660/actahortic.2008.796.7

Zanella A \& Rossi O (2015). Post-harvest retention of apple fruit firmness by 1-methylcyclopropene (1-MCP) treatment or dynamic CA storage with chlorophyll fluorescence (DCA-CF). European Journal of Horticultural Science 80(1): 11-17 https://doi.org/10.17660/ejhs.2015/80.1.2

(C) 2021 by the authors. Licensee Ankara University, Faculty of Agriculture, Ankara, Turkey. This article is an open access article distributed under the terms and conditions of the Creative Commons Attribution (CC BY) license (http://creativecommons.org/licenses/by/4.0/). 